\title{
Development of Active-Learning Units in Nuclear Engineering
}

\author{
Stephen U. Egarievwe \\ Alabama A\&M University, USA \\ stephen.egarievwe@aamu.edu
}

\begin{abstract}
Active learning engages students in activities that could enhance their ability to analyze, synthesize, and evaluate the material being learned. Evidence-based studies have shown that active learning increases student performance in Science, Technology, Engineering, and Mathematics (STEM) courses. This paper presents the design of active learning units in nuclear engineering. The goal is to enhance students learning and technical skills, thereby improving their preparation for success in pursuing STEM graduate programs and careers in nuclear engineering. Three modes of active learning that are of interest are problem-solving, lab-based hands-on activities, and simulation. The active learning units are aimed at using interactive mode to provide students with the mastering of fundamental principles and concepts, and better understanding of how equations translate and apply to reallife engineering situations. The introductory nuclear engineering topics to be covered include radioactivity and half-life, binding energy, atom density, radiation interactions, radiation dose, radiation shielding, stopping power, and fission. An assessment plan for the effectiveness of the active-learnings units is also presented.
\end{abstract}

Keywords -Active-Learning, Hands-On Learning, Nuclear Engineering, Problem-Solving, Simulation, STEM Education.

\section{INTRODUCTION}

$\mathrm{N}$ UCLEAR engineers are very important to the technical workforce of the nuclear and radiological industry. One major problem facing STEM education is the production of nuclear engineers that will replace the aging workforce in the nuclear industry. A 2015 survey shows that a high percentage of the nuclear workforce in the United States are nearing retirement [1]. As part of the solution to future shortages in the nuclear workforce, there are efforts and recommendations for government entities and industries to partner with universities to broaden participation by improving diversity enrollments in nuclear pipeline programs [1 -3$]$. There is increasing need to grow the nuclear workforce. As of 2017, there are 31 countries having 448 nuclear power plants [4]. Historically, nuclear power generation has been dominated by developed countries in North America, Europe, and Asia (particularly Russia), but increasing power demands has led to increase of the number of developing countries looking towards nuclear power generation, mostly by China, Bangladesh, India, and Pakistan [4]. As part of the solution to nuclear workforce development, 1) STEM programs need to expose students to early hands-on and the mastering of skills and science, engineering and technology principles needed in developing the nuclear workforce; and 2) there should be increased efforts in developing nuclear pipeline education initiatives that will enhance recruitment and retention activities, industry collaborations, and graduate-school/job placement drives. Some logical questions on nuclear workforce development and solution approaches from academic point of view are listed in Table 1 .

TABLE I

KEY QUESTIONS AND SOME SOLUTION APPROACHES IN NUCLEAR WORKFORCE DEVELOPMENT
Question

1 How can STEM curriculum enhance nuclear engineering skillset development?

2 How can we increase the retention and graduation rates of women and underrepresented minorities in nuclear engineering programs?

3 How can STEM programs address the problem of replacing the aging nuclear workforce?
Solution Approach and Activities

Integrated active learning and hands-on technical training.

Early alert and mentoring based on continuous assessment with improvement feedback.

Students-industry bridge activities and the broadening of participation of underrepresented minorities.
One of the successful models used in developing nuclear workforce pipeline is the Vertical Education Enhancement (VEE) model [5] that promotes collaborations between academic institutions, industries, government agencies, and local/regional communities, and has adequate funding and research supports. The VEE model has been used to develop a Nuclear Education and Research Vertical Enhancement (NERVE) program that spans recruitment outreach to secondary schools (middle/high schools) and two-year colleges, multitrack technical training in undergraduate programs, graduate school, and postdoctoral training [5]. The VEE model was also used successfully in faculty development and collaborations among international institutions [6]. This paper focuses on the curriculum development aspect of the VEE model where active-learning approaches are used to support technical training and skillset development. The goal is to 


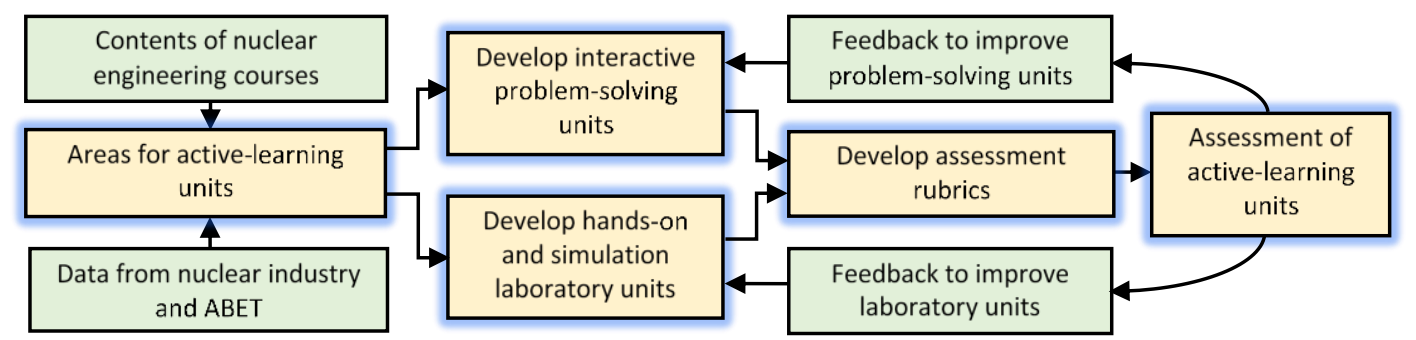

Fig. 1. Approach and methodology for developing and incorporating active-learning units into nuclear engineering courses. ABET is the Accreditation Board for Engineering and Technology.

develop innovative active-learning units to enhance undergraduate STEM education in nuclear engineering curricula.

Some of the recent efforts in nuclear workforce development are focused on the recruitment and undergraduate training stages of the education pipeline $[7,8]$. According to Karayaka et al. [7], one-on-one interaction with undergraduate students is the most effective tool in recruiting into nuclear scholarship programs. A survey of 31 nuclear scholarship students showed the about $80 \%$ of then were recruited through one-on-one with faculty advisors and mentors [7]. Other recruitment efforts used include emails, flyers, and peer interactions. In a project-based learning program for nuclear workforce development, students take courses in Engineering Practices and Engineering Capstone (an engineering senior design project class), along with professional training and technical classes that place emphasis on power generation [8].

\section{DESIGN APPROACH FOR THE ACTIVE LEARNING UNITS}

Active learning model is a learning model that engages students in class and/or laboratory activities that promote problem-solving [9], analysis, synthesis and evaluation of the material being learned. In active learning, the teaching is structured for students to participate in doing things instead of just listening. Teaching practices play major role in improving student learning in STEM education [10,11]. Evidence-based data confirms that active learning increases student performance in STEM courses [12]. In a study by Freeman et al. [12], Kernel density plots showed a $12 \%$ mean improvement in student learning in an active-learning classroom over a lecture classroom.

The three modes of active learning that are of interest in the present work include a) participation of student groups in problem-solving, b) participation of student groups in hand-on skill development, and c) the use of simulation in teaching and learning. Fig. 1 shows the approach and methodology that will be used in this work for developing and incorporating activelearning units into nuclear engineering courses.

\section{A. Problem-Solving Student Groups}

The problem-solving interactive units are aimed at mastering fundamental principles and concepts and better understanding of how equations/formulae translate and/or apply to real-life engineering situations. It also enhances the understanding of how different parameters in an equation interact with each other (such as dependency relationships). The practicality aspect is understanding how different components of an engineering systems function together to accomplish the goals for which they are designed. The problem-solving interactive units to be developed at the introductory nuclear engineering level are as follow:

i. Radioactivity and half-life.

ii. Binding energy.

iii. Atom density.

iv. Radiation interactions.

v. Radiation dose.

vi. Radiation shielding.

vii. Stopping power.

viii. Fission.

\section{B. Hands-On Student Groups}

This element of the active-learning units will enhance skillset development in nuclear engineering. Lab experiments will be designed to support nuclear skill-set development. The lab units will cover mostly nuclear instrumentation techniques and methods. See Table II.

TABLE II

TOPICAL AREAS FOR HANDS-ON ACTIVE-LEARNING UNITS

\begin{tabular}{|c|c|c|}
\hline Unit & Hands-On Lab & Knowledge and Skills to be Acquired \\
\hline 1 & $\begin{array}{l}\text { Nuclear Instruments } \\
\text { Electronics }\end{array}$ & $\begin{array}{l}\text { Understand and master basic nuclear } \\
\text { instrumentation electronics and techniques } \\
\text { in radiation measurements. }\end{array}$ \\
\hline 2 & $\begin{array}{l}\text { Geiger-Mueller } \\
\text { Counters }\end{array}$ & $\begin{array}{l}\text { Half-life determination, linear absorption } \\
\text { coefficient, and counting statistics. }\end{array}$ \\
\hline 3 & $\begin{array}{l}\text { Calibration of Gamma } \\
\text { Source and Radiation } \\
\text { Survey Meters }\end{array}$ & $\begin{array}{l}\text { Skills to calibrate a gamma standard } \\
\text { source and use that information to } \\
\text { calibrate radiation survey meters. }\end{array}$ \\
\hline 4 & $\begin{array}{l}\text { Gamma Spectroscopy } \\
\text { Using NaI Scintillation } \\
\text { Detectors }\end{array}$ & $\begin{array}{l}\text { Master the use of NaI scintillation } \\
\text { detectors. Radio-isotope identification } \\
\text { skills: identification and composition of an } \\
\text { unknown nuclear material. }\end{array}$ \\
\hline 5 & $\begin{array}{l}\text { Measurement of Dose } \\
\text { Using TLD and other } \\
\text { Dosimeter Systems }\end{array}$ & $\begin{array}{l}\text { Understand the use of thermo-luminescent } \\
\text { (TL) material and other dosimeter systems } \\
\text { to measure dose. Calibration curve for } \\
\text { gamma rays on TL dosimeters. }\end{array}$ \\
\hline 6 & $\begin{array}{l}\text { Radiation } \\
\text { Survey/Mapping }\end{array}$ & $\begin{array}{l}\text { Skills on surveying an area to locate } \\
\text { hidden radioactive materials. Skills to } \\
\text { survey areas of contaminations applicable } \\
\text { to nuclear power plants. }\end{array}$ \\
\hline 7 & Radiation Shielding & $\begin{array}{l}\text { Know how to apply the principles of As } \\
\text { Low As Reasonably Achievable } \\
\text { (ALARA) in radiation protection as } \\
\text { practiced in nuclear plants. }\end{array}$ \\
\hline 8 & Neutron Detection & $\begin{array}{l}\text { Skills on neutron activation measurements } \\
\text { of trace elements. }\end{array}$ \\
\hline
\end{tabular}




\begin{tabular}{|c|c|c|c|}
\hline $\begin{array}{l}\text { At time of entering the } \\
\text { course: } \\
\text { Collect data for } \\
\text { stratified randomization } \\
\text { among treatments - } \\
\text { GPA, Standardized test } \\
\text { (ACT), and Pretest } \\
\text { relevant to content. }\end{array}$ & $\begin{array}{l}\text { Control class: } \\
\text { Students in class with } \\
\text { no active-learning units. }\end{array}$ & $\begin{array}{l}\text { Assessment: } \\
\text { Two assessment types: } \\
\text { - Test on each class } \\
\text { module (active-learning } \\
\text { unit assessment). } \\
\text { - Course grade (overall } \\
\text { active-learning } \\
\text { assessment). }\end{array}$ & $\begin{array}{l}\text { Statistical Analysis: } \\
\text { Comparisons based on } \\
\text { stratified randomization } \\
\text { parameters (prior GPA, ACT, } \\
\text { and Pretest) using } \\
\text { assessment grades for } \\
\text { students within similar (prior } \\
\text { score) groups. }\end{array}$ \\
\hline
\end{tabular}

Fig. 2. Approach and experimental design for the research on the effect of active-learning on nuclear skill-set development.

\section{Simulation of Nuclear Systems}

Simulation is particularly very important for concepts and systems that cannot be made available in a student lab setting, such as reactor startup and shutdown. Simulation helps to enhance skill-set development, where students use software packages to design and simulate nuclear systems. Examples of simulation topical areas are:

i. Neutron interaction and flux distribution in a nuclear reactor core.

ii. Nuclear heat generation and heat transports in reactor elements.

iii. Power plant cooling systems.

iv. Power generation system efficiency.

\section{AsSESSMENT Plan for Active LeARNing Units}

The assessment plan designed for studying the effects of active learning on skillset development in nuclear engineering is shown in Fig. 2. It schematically shows the approach and experimental design for testing the active learning unit. To ensure reliability and consistency, the following criteria could be used to govern the students that will participate in the study groups:

i. Student Equivalence: Stratified randomization will be used to ensure that the comparison groups (activelearning group and control group) are similar as much as possible in terms of characteristics that may influence the outcome of the active-learning units. The parameters that will be used for student equivalence are GPA, standardized test (ACT), and pretest relevant to course module content. Students with equal number of score and GPA levels will be randomly assigned to the comparison groups: active-learning group and control group.

ii. Instructor Equivalence: According to Freeman et al. (2014), instructor equivalence means "whether the instructors in the lecture and active learning treatments were identical, randomly assigned, or consisted of a group of three or more in each treatment". In this study, the same instructor will be in both the active-learning group and control group classes. This meets the identical instructor requirement for instructor-equivalence.

iii. Examination Equivalence: The assessments that will be given to students in the active-learning group and the control group will be identical.

The assessment tools include posttests (for modules in a course), tests and exams. The assessment parameters are 1) post module test scores for assessing the effects of each activelearning unit (formative evaluation), and 2) class grade for assessing the overall effects of the active-learning model (summative evaluation).

\section{CONCLUSIONS}

This paper presented the design for developing active learning units to enhance students learning and technical skillset development in nuclear engineering. The active learning modes discussed include problem-solving, lab-based hands-on activities, and simulation. These are interactive learning modes that provide students with the mastering of fundamental principles and concepts, and better understanding of how equations translate and apply to real-life engineering situations. The topics to be covered at the introductory nuclear engineering level include radioactivity and half-life, binding energy, atom density, radiation interactions, radiation dose, radiation shielding, stopping power, and fission. In future work, the active learning units will be created, implemented, and tested. The effectiveness of the active-learning units on student learning will also be assessed.

\section{ACKNOWLEDGMENT}

This work was supported in part by the National Science Foundation (NSF) HBCU-UP Program through award number 1818732, the U.S. Department of Energy (DOE) National Nuclear Security Administration (NNSA) award number DENA0003980, and the U.S. Nuclear Regulatory Commission (NRC) through award 31310018M0035.

\section{REFERENCES}

[1] E. McAndrew-Benavides, "NEI's 2015 Nuclear Workforce Survey and Results," presented at the Nuclear Energy Institute (NEI) 2015 Nuclear Workforce Survey, Rockville, MD, USA, Oct. 19, 2015.

[2] American Physical Society, "Readiness of the U.S. Nuclear Workforce for $21^{\text {st }}$ Century Challenges," American Physical Society (APS) Panel on Public Affairs, Committee on Energy and Environment, June, 2008. Available online: https://www.aps.org/policy/reports/popareports/upload/Nuclear-Readiness-Report-FINAL-2.pdf. Accessed on: August 14, 2021.

[3] Center for Energy Workforce Development, "Gaps in the Energy Workforce Pipeline 2015 CEWD Survey Results," Available online: https://www.cewd.org/documents/surveyreport/CEWD2015SurveySum mary.pdf. Accessed on: August 14, 2021.

[4] F. Alam, R. Sarkar and H. Chowdhury, "Nuclear power plants in emerging economies and human resource development: A review," Energy Procedia, vol. 160, pp. 3-10, Feb. 2019, 10.1016/j.egypro.2019.02.111.

[5] S. U. Egarievwe, "Vertical education enhancement-a model for enhancing STEM education and research," Procedia-Social and Behavioral Sciences, vol. 177, pp. 336-44, Apr. 2015, 10.1016/j.sbspro.2015.02.354. 
[6] S. U. Egarievwe and R. B. James, "Faculty Development and International Collaborations Using Vertical Education Enhancement Model," presented at the 2015 ASEE International Forum, Seattle, WA USA, June 14, 2015. Available online: https://peer.asee.org/facultydevelopment-and-international-collaborations-using-vertical-educationenhancement-model. Accessed on: August 14, 2021.

[7] H. B. Karayaka, C. W. Ferguson and A. C. Thompson, "An Evaluation of Focused Outreach and Recruiting Efforts in a Nuclear-related Workforce Development Program," presented at the 2020 ASEE Virtual Annual Conference Content Access, Virtual Conference, June 22 - 26, 2020. Available online: https://peer.asee.org/an-evaluation-of-focusedoutreach-and-recruiting-efforts-in-a-nuclear-related-workforcedevelopment-program. Accessed on: August 14, 2021.

[8] H. B. Karayaka, C. W. Ferguson and A. C. Thompson, "Project-based Learning Program for Nuclear Workforce Development Phase II: Implementation," presented at the 2021 ASEE Virtual Annual Conference Content Access, Virtual Conference, July 26 - 29, 2021. Available online: https://peer.asee.org/project-based-learning-program-for-nuclearworkforce-development-phase-ii-implementation. Accessed on: August 14,2021
[9] J. R. Savery, "Overview of Problem-Based Learning: Definitions and Distinctions," in Essential Readings in Problem-Based Learning, A. Walker, H. Leary, C. E. Hmelo-Silver and P. A. Ertmer (Editors). West Lafayette, IN, USA: Purdue University Press, 2015, pp. 5-15.

[10] M. K. Smith, F. H. Jones, S. L. Gilbert and C. E. Wieman, "The Classroom Observation Protocol for Undergraduate STEM (COPUS): A New Instrument to Characterize University STEM Classroom Practices," CBE_Life Sciences Education, vol. 12, no. 4, pp. 618-27, Dec. 2013, 10.1187/cbe.13-08-0154.

[11] L. M. Cleveland, J. T. Olimpo and S. E. DeChenne-Peters, "Investigating the relationship between instructors' use of active-learning strategies and students' conceptual understanding and affective changes in introductory biology: A comparison of two active-learning environments," $C B E$ - Life Sciences Education, vol. 16, no. 2, ar19, Jun. 2017, 10.1187/cbe.16-060181.

[12] S. Freeman, S. L. Eddy, M. McDonough, M. K. Smith, N. Okoroafor, H. Jordt and M. P. Wenderoth, "Active Learning Increases Student Performance in Science, Engineering, and Mathematics," Proceedings of the National Academy of Sciences, vol. 111, no. 23, pp. 8410-8415, Jun. 10, 2014, 10.1073/pnas.1319030111. 